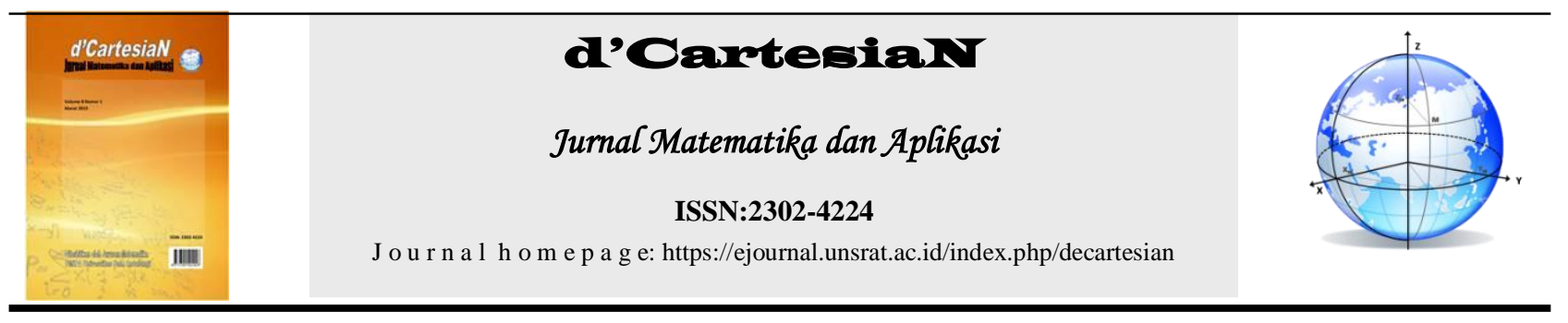

\title{
Analisis Multidimensional Scaling Untuk Jarak Antara Fakultas-fakultas serta Program Pasca Sarjana di Universitas Sam Ratulangi Manado
}

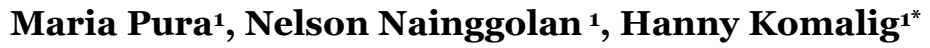 \\ ${ }^{1}$ Jurusan Matematika-Fakultas Matematika dan Ilmu Pengetahuan Alam-Universitas Sam Ratulangi Manado, Indonesia
}

*Corressponding author : hanoyo7@yahoo.com

\begin{abstract}
A B S T R A K
Multidimensional Scaling (MDS) merupakan teknik eksplorasi untuk memvisualisasikan kemiripan/ketakmiripan individu dalam ruangan dimensi rendah berdasarkan jarak. Kegunaan MDS adalah untuk menyajikan kemiripan objek-objek secara visual. Interpretasi keluaran MDS dapat mengarah pada pemahamanan yang mendasari kedekatan antara objek. Dalam penelitian ini, MDS digunakan untuk visualisasi jarak antara fakultas-fakultas serta pasca sarjana di Universitas Sam Ratulangi Manado dalam bentuk peta konfigurasi. Hasil dari data menunjukan bahwa plot MDS menunjukan adanya kedekatan antara FKM dan FIB berdekatan; juga FMIPA, Faperta, Fapet dan FKed berdekatan; serta FaPerik, FTeknik, FEkonomi, Fisip dan FHukum, juga saling berdekatan. Kecuali FIB, karena fakultas ini terlihat jauh dari Fakultas-fakultas yang lain. Nilai Stress dari MDS ini diperoleh sebesar adalah 0.12241 yang artinya tingkat kesesuaian model cukup baik.
\end{abstract}

INFO ARTIKEL

Diterima : 11 Maret 2019

Diterima setelah revisi : 23 Maret 2019

Tersedia online : 31 Maret 2019

\author{
Kata Kunci: \\ Multidimensional Scaling \\ Jarak Euclidien \\ Nilai Stress \\ Jarak antara Fakultas di UNSRAT
}

\section{Pendahuluan}

Multidimensional Scaling (MDS) adalah salah satu teknik analisis yang menyampaikan informasi yang berupa tampilan peta atau gambar dua dimensi yang menunjukkan posisi relative suatu objek dengan objek lainnya. Dengan tampilan ini, informasi yang ingin disampaikan akan lebih menarik, mudah dipahami dan mudah dianalisis. Peta MDS, dapat diketahui bahwa objek-objek yang memiliki nilai proximity (nilai kedekatan) besar akan terletak dalam jarak berdekatan pada peta yang artinya saling berdekatan antara objek, sedangkan objek-objek yang mempunyai nilai proximity (nilai kedekatan) kecil akan terletak dalam jarak saling berjauhan dari objek yang lain.

Universitas Sam Ratulangi (UNSRAT) mempunyai beberapa fakultas serta Program Studi, baik jejang Diploma, Sarjana, Magister, dan Doktor.

Jumlah fakultas di Universitas Sam Ratulangi Manado sekarang ada sebelas fakultas serta Program Pasca Sarjana yakni : (1) Fakultas Kedokteran (Fked).
(2) Fakultas Teknik (FTeknik). (3) Fakultas Pertanian (FaPerta). (4) Fakultas Peternakan (FaPet). (5) Fakultas Perikanan dan Ilmu Kelautan(FPIK). (6) Fakultas Ekonomi (FEkonomi). (7) Fakultas Hukum (FHukum). (8) Fakultas Ilmu Sosial dan Ilmu Politik (FISIP). (9) Fakultas Ilmu Budaya (FIB). (10) Fakultas Matematika dan Ilmu Pengetahuan Alam (FMIPA). (11) Fakulas Kesehatan Masyarakat (FKM). (12) Program Pasca Sarjana (Pasca) [1]. Tujuan dari penelitian ini Mendeskripsikan secara visual dengan menggunakan metode Multidimensional Scaling untuk jarak antara fakultas- fakultas serta pasca sarjana di Universitas Sam Ratulangi Manado.

\section{Analisis Multidimensional Scaling}

Multidimensional Scaling merupakan suatu teknik eksplorasi yang digunakan untuk memvisualisasikan kemiripan/ketakmiripan dalam ruangan dimensi yang rendah. MDS merupakan bagian 
dari analisis Multivariate, karena suatu objek seringkali melibatkan banyak variabel atau peubah yang menjadi atribut-atribut objek tersebut. Kegunaan MDS adalah untuk menyajikan objek-objek secara visual berdasarkan kemiripan yang dimiliki. Interpretasi dari keluar (output) yang dihasilkan MDS dapat mengarah pada pemahaman yang mendasari kedekatan antara objek. kegunaan MDS adalah untuk menyajikan objek-objek secara visual berdasarkan kemiripan yang dimiliki. Tujuan dari MDS adalah menemukan suatu konfigurasi sedemikian sehingga jarak antara titik sesuai dengan ketakmiripan antara objek. Ukuran yang digunakan untuk mengukur hubungan antara objek adalah proximity yang berarti "kedekatan" objek yang satu dengan objek lainnya. Proximity dapat berupa "kemiripan" $\left\{s_{r t}\right\}$ ataupun "ketakmiripan" $\left\{\delta_{r t}\right\}$ antara objek, dengan indeks $r$ dan $t$ melambangkan objek ke $r$ dan objek $t$ yang dibandingkan [2].

\section{$2.1 \quad J e n i s-j e n i s$ Multidimensional Scaling}

Berdasarkan tipe data skala pengukuran MDS dibagi menjadi dua jenis, yaitu multidimensional scaling metric dan multidimensional scaling non-metric [2].

\subsubsection{Multidimensional Scaling Metric}

Data jarak yang digunakan dalam MDS metric adalah data rasio dan interval. MDS metric digunakan untuk menemukan himpunan titik dalam ruang $n$ dimana masing-masing titik mewakili satu objek sehingga jarak $d_{r t} \approx f\left(\delta_{r t}\right)$, dimana $f$ adalah fungsi monotonik parametrik kontinu [2].

\subsubsection{Multidimensional Scaling Non-metric}

MDS non-metric menunjukan bahwa skala pengukuran datanya nominal atau ordinal, sehingga nilai kedekatan mempunyai sifat ordinal. Hasil dari MDS non-metric adalah jarak dalam ruang yang dihasilkan hanya berada pada tingkat yang sama dengan data asli [2].

\section{Nilai Stress (Standardized Residual Sum of Square) Dalam MDS}

Tingkat kesesuaian model (goodness of fit) menggunakan ukuran kriteria kesalahan (lack of fit or error) STRESS. Program ALSCAL mengandung proses iterasi, setiap iterasi terdiri dari dua langkah utama yakni mengubah data berupa jarak antara pasangan objek menjadi ukuran baru yang disebut disparities dan menduga koordinat setiap objek berdasarkan jarak dan disparities [3].

$$
\text { Stress }=\sqrt{\frac{\sum_{i<j}^{n}\left(\boldsymbol{d}_{i j}-\widehat{\boldsymbol{d}}_{i j}\right)^{2}}{\sum_{i<j}^{n} \boldsymbol{d}_{i j}^{2}}}
$$

dimana $d_{i j}$ adalah jarak antara objek ke- $i$ dan objek ke$\mathrm{j}$ dan $\widehat{\mathrm{d}}_{\mathrm{ij}}=$ disparities antaraa objek ke-i dan objek ke-j. Semakin kecil nilai Stress menunjukan bahwa hubungan monoton yang terbentuk antaraa ketidaksamaan dengan disparities semakin baik (didapat kesesuaian) dan kriteria peta persepsi (perceptual map) yang terbentuk semakin sempurna [3].

\section{Metodologi Penelitian}

Data yang digunakan dalam penelitian ini adalah data jarak fakultas-fakultas serta pasca sarjana menurut google map [4]. Pengukuran jarak antara fakultas-fakultas serta program pasca sarjana dengan aplikasi google map perencanaan rute yaitu kendaraan roda empat (mobil) dan bukan jarak yang diukur secara langsung atau jarak terdekat antaraa dua titik.

Metode analisis data yang digunakan dalam penelitian ini adalah analisis Multidimensional Scaling. MDS digunakan untuk merepresentasikan kedekatan antara objek, dalam hal ini adalah fakultasfakultas serta program pasca sarjana dalam bentuk peta spasial.

$$
\text { Langkah-langkah untuk analisis }
$$
multidimensional scaling sebagai berikut:

a. Diukur jarak antara fakultas-fakultas serta pogram pasca sarjana di UNSRAT diukur menggunakan google map.

b. Dihitung jarak euclidien antara fakultas-fakultas serta program pasca sarjana.

c. Dihitung tingkat kesesuaian model melalui perhitungan nilai Stress.

\section{Hasil Dan Pembahasan \\ 5.1 Hasil Analisis Multidimensional Scaling}

Gambar 1 adalah hasil hitung jarak Euclidean antara fakultas-fakultas serta program pasca sarjana, data jarak ini yang akan diperoleh titik-titik koordinat stimulus yang kemudian menunjukan letak posisi jarak antara fakultas-fakultas serta program pasca sarjana, seperti berikut gambar dibawah ini: 
Analisis Multidimensional Scaling Untuk Jarak Antara Fakultas-fakultas serta Program Pasca Sarjana di

Universitas Sam Ratulangi Manado

d'Cartesian : Jurnal Matematika dan Aplikasi, Vol. 8, No.1 (Maret 2019) : 65-68

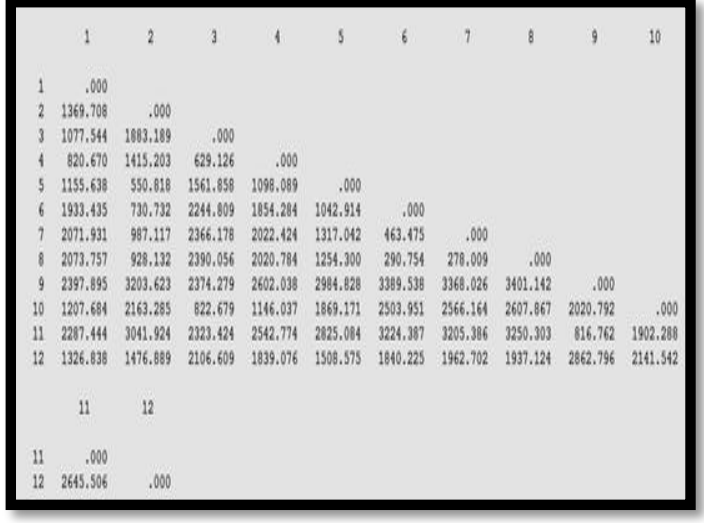

Gambar 1 Plot matrik jarak euclidean antara fakultas-fakultas serta program pasca sarjana di Universitas Sam Ratulangi Manado

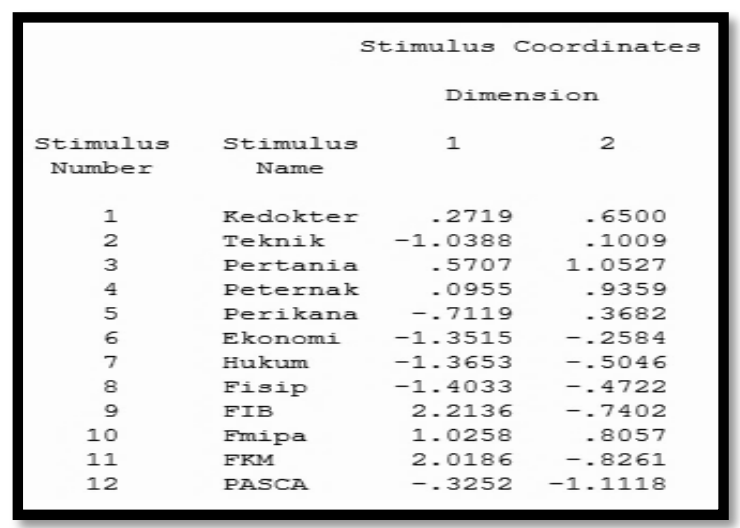

Gambar 2 plot titik kordinat stimulus dalam dua dimensi untuk jarak antara fakultas-fakultas serta program pasca sarjana

Gambar 2 adalah titik-titik kordinat yang akan mengambarkan posisi jarak antara fakultas-fakultas serta program pasca sarjana pada plot MDS pemetaan dua dimensi seperti gambar dibawah ini:

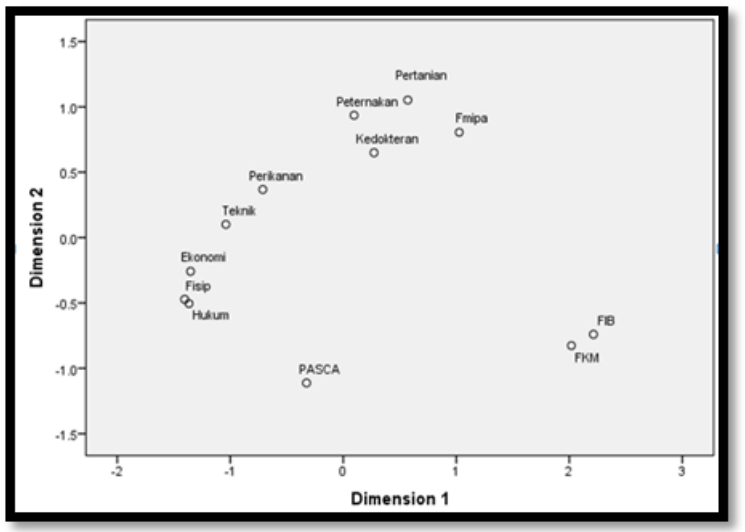

Gambar 3 Plot MDS pemetaan untuk jarak antara Fakultasfakultas dan pasca sarjana di Universitas Sam Ratulangi Manado
Gambar 3 adalah plot pemetaan yang mendeskripsikan secara visual untuk jarak antara fakultas-fakultas serta program pasca sarjana. Di dalam plot pemetaan untuk jarak fakultas serta program pasca sarjana terlihat yang memiliki kedekatan adalah sebagai berikut:

- $\quad$ FIB dan FKM

- $\quad$ FMIPA, FaPerta, FaPet, dan FKed

- $\quad$ FPIK, FTeknik, FEkonomi, Fisip dan FHukum

Sedangkan untuk program pasca sarjana memilki tempat tersendiri dan terlihat jarak jauh dari fakultas lain itu karena nilai kedekatan lebih kecil dibandingkan dengan fakultas yang lain.

\section{Kesimpulan}

Analisis MDS menunjukan adanya kedekatan antara. FKM dan FIB; FMIPA, FaPerta, FaPet dan FKed, saling berdekatan; FPIK, FTeknik, FEkonomi, Fisip dan FHukum, saling berdekatan. Nilai Stress yang diperoleh sebesar adalah 0.12241 yang artinya tingkat kesesuaian model cukup baik.

\section{REFERENSI}

[1] Info Kampus Indonesia. 2011. Profil Universitas Sam Ratulangi. http://www.kampusinfo.com/2011/09/profil-universitas-samratulangi.html [diakses 18 April 2017].

[2] Matijik, A.A., dan Sumertajaya, I.M., 2011. Sidik Peubah Ganda. Kampus IPB Darmaga. Bogor.

[3] Sihombing, I, D, 2016. Laporan Hasil Penelitian Analisis Multivariat dengan Metode Multidimensonal Scalling Untuk Peningkatan Proses Mengajar (PBM) Di FKIP UHN Medan. Lembaga Penelitian Universitas HKBP Medan.

\section{[4] https://www.google.co.id/maps/place/Unsrat/}

Maria Pura ( mariadewyo5@gmail.com )

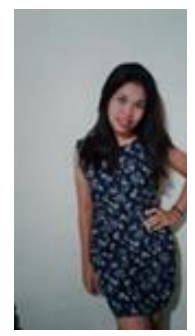

Lahir di Buo, Maluku utara pada tanggal 17 mei 1993. Mengakhiri studi perguruan tinggi Jurusan Matematika, FMIPA, Universitas Sam Ratulangi Manado, Tahun 2017 adalah tahun terakhir studinya. Makalah ini merupakan hasil penelitian skripsinya yang dipubikasikan 
Hanny Komalig ( hanoy07@yahoo.com )

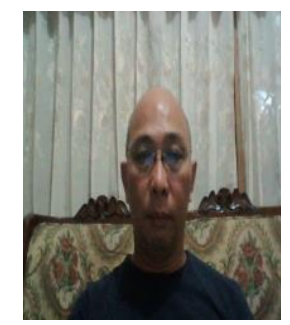

UNSRAT.

Lahir pada tanggal 6 Maret 1968. Pada tahun 1991 mendapatkan gelar Sarjana yang diperoleh dari Universitas Sam Ratulangi Manado. Gelar Master Sains (M.Si) di Institut Pertanian Bogor pada tahun 1999. Ia sebagai Pengajar tetap di

Nelson Nainggolan ( $\underline{\text { n-nelson@unsrat.ac.id ) }}$

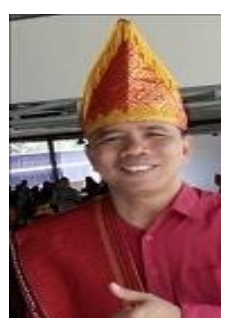

Lahir pada tanggal 9 Maret 1967. Pada tahun 1992 mendapatkan gelar Sarjana yang diperoleh dari Universitas Negeri Medan. Gelar Master Sains (M.Si) di Institut Teknologi Bandung pada tahun 1996. Ia sebagai pengajar tetap di UNSRAT. 